\title{
Correction to: Lonoctocog Alfa: A Review in Haemophilia A
}

\author{
Zaina T. Al-Salama ${ }^{1} \cdot$ Lesley J. Scott ${ }^{1}$
}

Published online: 3 March 2018

(C) Springer International Publishing AG, part of Springer Nature 2018

\section{Correction to: Drugs 77(15):1677-1686 (2017) https://doi.org/10.1007/s40265-017-0815-0}

The article Lonoctocog Alfa: A Review in Haemophilia A, written by Zaina T. Al-Salama and Lesley J. Scott, was originally published Online First without open access. After publication in volume 77 , issue 15 , pages $1677-1686$ CSL Behring $\mathrm{GmbH}$ requested that the article be Open Choice to make the article an open access publication. Post-publication open access was funded by CSL Behring GmbH. Further details may be found at http://www.medengine.com/ Redeem/CBD8F060224F2E65. The article is forthwith distributed under the terms of the Creative Commons Attribution-NonCommercial 4.0 International License (http://creativecommons.org/licenses/by-nc/4.0/), which permits any noncommercial use, duplication, adaptation, distribution and reproduction in any medium or format, as long as you give appropriate credit to the original author(s) and the source, provide a link to the Creative Commons license and indicate if changes were made.

The original article can be found online at https://doi.org/10.1007/ s40265-017-0815-0.

\footnotetext{
Zaina T. Al-Salama

demail@springer.com

1 Springer, Private Bag 65901, Mairangi Bay, Auckland 0754, New Zealand
} 